\title{
INFLUENCE OF CORRUPTION ON THE PERFORMANCE OF SECONDARY SCHOOL GEOGRAPHY STUDENTS IN JOS NORTH, PLATEAU STATE, NIGERIA
}

\author{
Saidu, Shuaibu Sada \\ Department of Geography \\ Nasarawa State University, Keffi, Nasarawa, Nigeria
}

\author{
Micah, Monday Ehud \\ Department of Technical Education \\ Babcock University High School, Ilisan-Remo, Ogun, Nigeria
}

\begin{abstract}
This paper looks at the issue of corruption in Secondary School and how it affects the performance of geography students in Jos North, Plateau State. The paper examines how corrupt practices are carried out by teacher by absenteeism from their primary assignment, running side businesses, and having dual appointments. The issue of parents encouraging corruption by cutting corners to ensure their wards graduate secondary school with good results was deeply discussed. Search light was also beamed on the problem of truancy among geography students and how it mares their performance. Government and proprietors' contribution to the overwhelming influence of corruption was not left out as lack of proper supervision, remuneration, infrastructural deficit and poor funding/absence of subvention to public secondary schools are some of the major factors blamed for the fall of education standard and its resultant consequences on the students' academic performance. Eight recommendations were provided to mitigate the influence corruption on the academic performance of geography students
\end{abstract}

Keywords: Education, Corruption, Secondary school. Geography

\section{INTRODUCTION}

Nigeria has a reputation for being a corrupt state; it is so bad that David Cameron described it as fantastically corrupt. The federal government has been having a long battle with corruption with no hope of bringing it to an end in a short distant time. This societal plaque has infested all aspects of the country's governance, social life, health care delivery, security service, criminal justice and education system. The Nigerian education system is suffering a terrible set back due to the issue of corruption. Corruption has become a major problem that need to be addressed so as to ensure that secondary school students in Nigeria achieve academic success. Corruption is a cankerworm that can destroy the education sector of a country. It occurs in different manners and at different levels causing the whole educational process questionable and unreliable. Many secondary school students believe that they do not need to study hard because at the end they will be assisted to pass their final examination. The effect of corruption is evident in the wide spread malpractices in examination centres, dubious admission process, premature nature of youngsters gaining admission into universities and the half-baked graduate they will eventually become after graduation,

[1] states that, in an educational system, the performance of a teacher is one of the factors used in determining school effectiveness and learning outcomes because teachers' interaction with learners is the pathway on which educational quality turns. Unfortunately, they are mostly at the centre of most corrupt practices perpetrated at secondary school level.

According to [2], Corruption among adults is a vice that is being passed on young people and this is evident in senior secondary schools in Nigeria. The failure of government in funding public secondary schools has given room for more Private Secondary Schools to spring up. Unfortunately, the private schools are also not left behind in corrupt practices. [3] discovered that parents in their quest to have their wards pass their examination and meet up with their counterpart in the university, take their children to private schools. This make the schools special centres where children will register to write their final examination without stress of reading and these private schools have been involved in the corrupt practices of making sure these students pass their examination without respect to policies on Education.

[4] said that the Teachers' Service Commission (TSC) has been ranked as one of most corrupt government agency after the Kenya Police for many years. He went further to say corruption is wide spread in other areas but seems more rampant in education because of the number of teachers involved. A pilot Study on Quiet Corruption in Public Education Institutions in Lagos State carried out by [5] reported that, Absenteeism, sexual harassment, compulsory sales of study materials, favoritism, sex for grades have become the order in many public education institutions. These are derivatives of lack of adequate funding of education institutions 
by government and the poor remuneration of teachers and lecturers. In primary and secondary education institutions in particular, head teachers are not properly funded so they can manage the schools under them. As a result, they resort to demanding money from pupils and students and extorting them under the guise of making provision for teaching materials which are not available.

In all public schools, the students' representative council, as a body, has unfettered access in the reportage of issues such as sexual harassment or adverse issues or events through a direct line. Sadly, the monitoring mechanism which the government has put in place, such as the students' representative council, assessment template for school teacher, evaluation schedule all do not have as its focus the monitoring of quiet corruption. For instance, there is no mechanism for monitoring absenteeism from class, conducting extra lesson for money or the compulsory sales of study materials to students.

Public secondary schools are also involved in corruption when a principal or teacher accepts, solicits, or extorts a bribe from the students or parents. It is also abused when private secondary schools' proprietors or teachers also actively offer bribes to circumvent education policies and processes for competitive advantage and profit. Public schools can be abused for personal benefit even if bribery does not occur, through patronage and or nepotism. Of course, this should not be taken to mean that corruption cannot occur at other levels or its effects are only major in private secondary schools. Some parents also intend to send their children to private schools primarily to enable their children obtain excellent results and on the other hand support examination malpractices which have in turn degraded the quality and standard of education in Nigeria [3].

\section{THE CONCEPT CORRUPTION}

Corruption has been seen as a primary impediment to growth, with dramatic consequences in the developing world [6]. Because corruption is characterized by many trends and manifestations, many scholars and institutions provide definitions of corruption that contain the trends and manifestations of corruption in their own environment or locality. This feature of corruption helps to make discussions that are focused on corruption more elastic and robust because a feature of corruption in one country that is absent in another can help illuminate more lights on how people in another culture or setting can understand and explore the same concept as well as solve its multi-faceted problems. This, in a way means that corruption comes in layers or hierarchies. Layers or hierarchies of corruption could refer to the class of persons involved in corruption and corrupt practices, the modus operandi of corruption or the prevalence of corruption among a people in a state [7].

\section{CORRUPTION IN EDUCATION}

In Africa many people see corruption as a practical problem involving the "outright theft, embezzlement of funds or other appropriation of state property, nepotism and the granting of favours to personal acquaintances, and the abuse of public authority and position to exact payments and privileges" [8]. The wide spread or prevalence of corruption in Nigeria means that there is hardly any sector of the Nigerian society that can be exempted as not being corrupt. Be this as it may, there are sectors in which the prevalence of corruption in them have a terrible and disastrous consequence and one sector where this is real is education. This position is taken because corruption in the education industry is terribly detrimental to the moral and general health of the Nigerian state [7]. Unfortunately, corruption has filtered into almost every sphere of the Nigerian Economy, including the educational sector, and this has contributed to the country's education crises, where an increasing number of children are failing to go to school [9].

Corruption in education is a serious blight that undermines the quality and availability of schools and universities around the world, according to international report. In some countries the report says that almost three-quarters of people in Cameroon and Russia see their education systems as "corrupt or highly corrupt" [10]. There seems to be huge range of nepotism, bribery, high level of dishonesty, illicit charges in the education system, which retard the development of the educational system in Nigeria. [8] define education corruption as the abuse of authority for both personal as well as material gain. An education system can be corrupt in four ways: (i) through its education functions, (ii) through the supply of goods and services, (iii) through professional misconduct, and (iv) in the treatment of taxation and property. These can include the assessment of student achievement.

Corruption lays in wait for learners in Nigeria on the day of their first attempt to gain entry or entrance into the gates of pre-primary education and remains through the other tiers of the education system. Common sense shows that security men at the gates of educational institutions in Nigeria receive bribes from parents, students and visitors and consequently involve themselves in corrupt and fraudulent practices that emotionally impose siege mentality not only on learners but on other stakeholders and consequently threaten and disrupt meaningful academic activities. In addition, those entrusted with security responsibilities in educational institutions in Nigeria easily compromise in their duties when bribes are given to them. That the security units in Nigeria's education industry can be neckdeep in corruption and corrupt practices show the magnitude of corruption in the education industry in Nigeria [7].

\section{CORRUPTION AND ITS IMPLICATION ON SECONDARY SCHOOL EDUCATION}

[2] identified the three most pronounced corrupt practices in secondary schools as, examination malpractice, 
cultism and sexual immorality. Corrupt practices are causing the lowering of education standard, poor attitude to work among students and staff, disrespect to staff by students and graduation of half-baked graduates. The pronounced corrupt practices identified by [2] are also found in the secondary schools in Jos North of Plateau State.

[11] has found that in 2007, when the administration of former Governor Jonah Jang of Plateau State declared a "state of emergency" in the education sub-sector due to the deplorable state of infrastructure in public schools in the state, many heaved a sigh of relief believing that the sub-sector would receive a boost that will make teaching and learning a desirable exercise. Few years down the line, Vanguard Learning discovered that nothing seemed to have changed as there is no tangible improvement in infrastructure in the public schools in the state. Taking a critical look at facilities in Government Secondary School, Utan, Jos North Local Government Area, Government Secondary School, Nyango, Jos South Local Government Area and Government Secondary School, Fuska Mata, Bassa Local Government Area which have benefited from these interventions as well as a cursory look at other public schools across the three senatorial zones of the state, one wonders where the funds earmarked for such projects were spent.

The embezzlement of public fund meant for funding of Secondary Schools have been siphoned to other businesses making these Schools not learning friendly for the teachers and students. This makes it difficult for teachers to teach and the students to learn. The performance of students will drastically reduce in all subjects including geography. [4] said Corruption has very long lasting consequences because resources are wasted, young people are denied the education they should receive, and those unable to afford bribes are denied access to schooling (both primary and secondary education). A generation of students comes to believe that personal effort and merit do not count and that success comes through manipulation, favoritism, and bribery.

\section{INFLUENCE OF CORRUPTION IN THE PERFORMANCE OF SECONDARY SCHOOL GEOGRAPHY STUDENTS}

Many students have developed phobia for map reading due to poor methodology or bad/wrong approach of teaching it. Unfortunately, many incompetent teachers through corrupt means have found their way into the classroom. Most times students are over - tasked in practical classes and their field trip/work poorly organized rendering the whole process a sham and the money paid by parents become a waste of resource. Geography is a subject that involves many outdoor activities; as a result, field trip/work is very important event for geography students to perform well. But due to corruption, the students are asked to pay money which is underutilized or embezzled, consequently, the desired or the targeted knowledge is not gotten eventually.
It is a general belief that truancy among geography students can affects their performance; this is because geography is a very broad subject that needs their commitment. In as much as the students need to be available to be taught, lack of commitment in the side of the teachers also affects their performance. It is observed that, Geography teachers who do not complete their scheme of work because of lack of commitment contribute to the decrease in the performance of their students in Jos North, Plateau State.

Many teachers in both primary and secondary schools are frequently absent from schools without requisite permission from the school authorities. Head teachers fail to take measures, because some of the teachers will corrupt their way back to schools even if they are found guilty of being away from school without permission. In some of the schools, teachers were found to be engaged in businesses during school time and at the expense of their work [4]. [12] has found that the Plateau State Government has threatened to sack 155 teachers holding dual appointments with local and state government. The Chairman of Plateau State Teachers Service Commission, Vonjen Lar has found out that out of the 834 teachers recruited for its secondary schools, the State Universal Basic Education Board (UBEC) already engaged 155 as teachers in primary schools. It is a gross misconduct for some of these teachers to maintain the two appointments at the detriment of the students. The resultant effect will lead to inability of the teacher to cover the scheme of work or follow it diligently. Eventually, at the end of the term the teacher will have no choice but to rush the scheme of work not minding whether the students understand or not.

A closer Look at the boarding secondary schools in the state, suggests that most of the school managements do not spent money allocated for feeding of the students accordingly. This causes the students to be fed with less quantity of poor nutrition diet thereby impeding their concentration in the class. When a child goes to class unsatisfied or hungry, his/her performance will be affected in all subjects, including geography. The issues of inadequate facilities such as wellfurnished classrooms, library, geography laboratory, up-to-date textbooks, and teaching aids also have a great effect on the performance of geography students, because they all aid in teaching the subject well. Nevertheless, corruption has made them not available due embezzlement and misappropriation. The problem of ghost workers is a major issue destroying the performance of geography students. It has been observed by the researcher that there are many schools that have geography teachers only on record but when you visit the class the teacher is nowhere to be found. In this case, the students don't even have the knowledge they paid for.

\section{THE INFLUENCE OF CORRUPTION ON PARENTS}

Parents have lost interest in sponsoring their wards in various school extracurricular activities such as geography field trip because, they believe their money is not managed well in order for their wards to get the knowledge paid for. Their attitude 
toward payment of school fees is not encouraging because they have lost faith in the educational system. Others prefer sending their ward to learn skills or trade that will make them self-reliant because of fear that after spending so much to train their children; they might end up not doing well in external examination or securing job after graduation. Other parents in the quest to ensure their wards pass their final examinations with very good grades have resolved in sending them to private school or special centres where all sort of corrupt malpractices are carried out to ensure student pass their examinations at once.

\section{CONCLUSION}

[13] stated that, corruption in the education sector in the country is one social problem that has lowered the quality and standard of education in Nigerian and requires immediate solution. They also found out that academic corruption to a great extent has negative effect on students' academic achievements not minding their high grades. Academic corruption induces disinterest on the students to hard work and bad study habits. It also makes them seek to cut corners in all they do to achieve success. It lowers the standard and quality of education and has a big negative impact on the society, as most of them would be future leaders lack the required competences and moral foundation to lead or earn a decent living. This is obviously why the rate of corruption and moral decadence is heightening rapidly without restrain in the country.

This paper is so concern about secondary school corruption because the negative power of corruption when not fought or destroyed from this level will give birth to a serious problem in tertiary institution. Corruption nurtured from secondary school will be very difficult to combat when the corrupt persons move to the tertiary institution.

\section{RECOMMENDATION}

The following recommendations were made:

1. Students should be encouraged to report any teacher who failed to carry out his/her responsibility very well. This is mostly rampant in public secondary schools where due to lack of proper monitoring teacher tent to have conflicting interest with their primary assignment.

2. For geography teacher to perform their duties credible, they should be provided with modern facilities such as fully furnished geography laboratory, teaching aids, up-to-date geography text books and maps, field trip gadget and allowance and better remuneration.

3. Competent/qualified teachers are required for effective teaching of geography and map reading therefore, government and proprietors/employers should ensure that only trained geography teachers are employed to teach the subject.

4. Government and other relevant responsible bodies should endorse teaching ethics. Examination malpractice and other forms of corrupt practices perpetrated by school authorities and teachers must be welcomed with immediate and stiffer penalties so as to sanitize the system.

5. School administrators should be involved in the organization of field trips. This will help in moderating the price and evaluating the relevance of the targeted field area of trip. Involvement of school authorities will also checkmate the possibility of siphoning money paid by students for the trip. A comprehensive report about the field trip should be properly documented to serve as a reference point.

6. Parents should partner with teachers and school management to ensure their wards are not involved in truancy. Geography is indeed a broad subject hence; no student will perform satisfactorily with inconsistent attendance.

7. It is very pertinent that secondary schools should have a supervisory and disciplinary panel to monitor and check teachers who are always absent from class or those who have other business conflicting with their primary assignment of teaching.

8. The government should reorganize its education inspectorial and monitoring agencies to be more effective, technology driven and closer to schools in every community irrespective of location.

\section{REFERENCE}

[1] Volunteer Service Oversea. (2002). What makes teachers tick? A Policy Research Report on Teachers' Motivation in Developing Countries. London. VSO. Retrieved, from http://www.vso.org.uk

[2] Daniel, D. W. (2015) Identifiable Corrupt Practice among Staff and Students of Secondary Schools in Delta State of Nigeria. International Journal of Secondary Education. Vol.3, No.5, (Pg50-54).

[3] Nwankwo, B. C., and Nweke, P.O. (2016). Effects of Corruption of Educational System. A Focus on Private Secondary Schools in Nsukka Zone. Global Journal of HumanSocial Science. Art and Humanities Psychology. Vol 16 iss.5 version 1.0 .

[4] Taaliu, S. T. (2017). Corruption in Schools and Universities in Kenya. Open Journal of Social Sciences, 5, (Pg227-231). https://doi.org/10.4236/jss.2017.54020

[5] Human Development Initiatives. (2016). Quiet Corruption in Public Education Institutions in Lagos State. A Pilot Study. ISBN: 978-978-969-429-7.

[6] Daniel, K., and Pedro, C.V. (2005). Legal Corruption. Siteresources.worldbank.org.

[7] Nwaokugha, D. O., and Ezeugwu, M.C. (2017). Corruption in The Education Industry In Nigeria: Implications for 
National Development. European Journal of Training and Development Studies Vol.4, No.1, (Pg1-17).

[8] Pierre du Plessis. (2014). Corruption in Education - Stealing the Future. Mediterranean Journal of Social Sciences MCSER Publishing, Rome-Italy. Vol 5 No 23. (doi 10.5901)

[9] Samuel, O.G. (2018). How Corruption is Affecting Basic Education in Nigeria. International Anti-Corruption

Conference.

[10] Coughlan, S. (2013, October 9). Corruption and Bribery in the Classroom. BBC News Retrieved from

https;//www.bbc.com/news/business-2444459.

[11] Marie-Therese, N. (2018, February 15). Students, Teachers Decry Dearth of Learning Space in Jos. Vanguard. Retrieved from https://www. vanguardngr.com/2018/02/studentsteachers-decry-dearth-learning-space-jos/

[12] Tauna. A. (2018, April 15). 155 Teachers in Plateau State to lose Jobs over Dual Appointment.Daily Post. Retrieved from https://dailypost.ng/2018/04/15/155-teachers-plateau-statelose-jobs-dual-appointment/

[13] Aniodoh, H. C. O.; Ebouh. C. N., and Nweke, J.O. (2017). Academic Corruption and Students Achievements in Tertiary Institutions in Enugu State International Journal of Progressive and Alternative Education, Volume 4 No. 1, August, 2017. Issn: 2408 - 6452. (Pg170-182). 